\title{
FAKTOR-FAKTOR YANG MEMPENGARUHI PEMBERIAN ASI PADA BAYI NEONATAL DI RSIA PERTIWI MAKASSAR
}

\author{
Aswita Amir ${ }^{1}$, Nursalim ${ }^{1}$, Aliffiani Widyansyah ${ }^{2}$ \\ ${ }^{1}$ Jurusan Gizi, Politeknik Kesehatan Kemenkes, Makassar \\ ${ }^{2}$ Alumni Prodi D-IV, Jurusan Gizi, Politeknik Kesehatan Kemenkes, Makassar \\ Korespondensi : E-Mail : aswitaamir@poltekkes-mks.ac.id
}

\begin{abstract}
Breastmilk contains high immune antibodies and killer germs that can reduce the risk of infant mortality but exclusive breastfeeding coverage in Indonesia is only $55,7 \%$ and has not reached the government target of $80 \%$. This study aims to determine the relation between delivery process of baby, breast crawl and mother's knowledge with exclusive breastfeeding at RSIA Pertiwi Makassar.The research is an analytical research with cross sectional design. Samples of this study are 155 newborn babies at RSIA Pertiwi Makassar. Data collected by interview using questionnaire then analyzed by Chi Square Test. The results show that there are 54,2\% respondents who gave exclusive breastfeeding. There are $59,4 \%$ respondents with normal delivery process. There are 20,6\% respondents who did breast crawl. Thera are 11,6\% respondents with good knowledge. The result of statistical test shows that there are relation between delivery process of baby, breast crawl, and mother's knowledge with exclusive breastfeeding.
\end{abstract}

Keywords: Breast crawl, delivery process of baby, exclusive breastfeeding, mother's knowledge

\section{PENDAHULUAN}

Pemberian ASI eksklusif dapat mengurangi risiko kematian pada bayi karena ASI mengandung kolostrum yang kaya akan antibodi untuk daya tahan tubuh dan pembunuh kuman dalam jumlah tinggi. Selain itu, ASI juga mengandung zat penyerap berupa enzim tersendiri yang tidak akan mengganggu enzim di usus (Kemenkes RI, 2016). Berdasarkan Peraturan Pemerintah Nomor 33 Tahun 2012 Air Susu Ibu (ASI) eksklusif adalah ASI yang diberikan kepada bayi sejak dilahirkan selama enam bulan, tanpa menambahkan dan/atau mengganti dengan makanan atau minuman lain (kecuali obat, vitamin dan mineral).
United nation childrens fund (UNICEF) dan World Health Organization (WHO) merekomendasikan sebaiknya anak hanya diberi air susu ibu (ASI) paling sedikit selama 6 bulan. ASI Eksklusif dianjurkan pada beberapa bulan pertama karena ASI tidak terkontaminasi dan mengandung banyak zat gizi yang dibutuhkan anak pada usia tersebut .

Di Indonesia, pemerintah telah memprioritaskan program pemberian ASI khususnya ASI eksklusif melalui Gerakan Nasional Peningkatan Pemberian ASI (PPASI) pada tahun 1990. Pada tahun 2012, pemerintah menerbitkan Peraturan Pemerinah tentang Pemberian Air Susu Ibu Eksklusif (PP Nomor 33 Tahun 2012) yang mengatur tugas dan tanggung jawab 
pemerintah dan pemerintah daerah dalam pengembangan program ASI. Dalam rangka mendukung keberhasilan menyusui, sampai tahun 2013, telah dilatih sebanyak 4.314 orang konselor menyusui dan 415 orang fasilitator pelatihan konseling menyusui.

Cakupan ASI eksklusif di Indonesia belum mencapai hasil yang diharapkan yaitu sebesar $80 \%$. Berdasarkan data Ditjen Gizi dan KIA Kemenkes RI, cakupan pemberian ASI eksklusif secara nasional pada tahun 2015 sebesar 55,7\%. Sementara itu, persentase bayi baru lahir yang mendapat Inisiasi Menyusu Dini (IMD) sebesar 49.7\%. Hal ini menunjukkan bahwa praktik IMD di Indonsesia masih belum maksimal. Di Sulawesi Selatan, cakupan pemberian ASI eksklusif pada bayi $0-6$ bulan hanya sebesar $71.5 \%$ dimana cakupan tersebut masih kurang dari target yang ditetapkan pemerintah (Kemenkes, 2016).

Berdasarkan penelitian yang dilakukan di RSIA Pertiwi Makassar ditemukan sebesar $30.8 \%$ bayi tidak diberikan ASI eksklusif dalam satu bulan pertama kehidupan dan persentase ibu yang tidak melakukan IMD sebesar 59.6\% (Amir, 2016). Hal ini menunjukkan bahwa target pemberian ASI eksklusif belum tercapai dan sebagian besar ibu tidak melakukan IMD.

Menurut Djami, dkk (2013) faktor - faktor yang dapat mempengaruhi pemberian ASI eksklusif antara lain karakteristik ibu (pengetahuan, pendidikan, pekerjaan, usia, paritas dan etnis), karakteristik bayi (berat lahir dan kondisi kesehatan bayi), lingkungan (keyakinan, dukungan keluarga, tempat tinggal dan sosial ekonomi) dan pelayanan kesehatan (pemeriksaan kehamilan, konseling laktasi, tempat persalinan, penolong persalinan dan kebijakan). Semua faktor tersebut memiliki kontribusi tersendiri dalam terciptanya perilaku yang diharapkan dalam pemberian ASI eksklusif.
Proses pemberian ASI pada prinsipnya ditentukan oleh tingkat pengetahuan seorang ibu. Semakin tinggi tingkat pengetahuan seseorang tentang ASI maka akan mempengaruhi pola pikir dan sikap orang tersebut (Rachmaniah, 2014).

IMD merupakan kunci yang sangat penting dalam keberhasilan menyusui. Hal in disebabkan karena bayi yang melakukan IMD sudah berusaha menyusu sendiri di awal kelahirannya sehingga membuat proses menyusui lebih efektif karena bayi dapat melekat dengan baik (Umar, 2014).

Kondisi psikis ibu sangat berpengaruh dalam produksi ASI. Kondisi psikis seperti kelelahan, ketidaknyamanan, dan nyeri merupakan kondisi psikis yang sering ditemukan setelah persalinan khususnya persalinan dengan operasi caesar (Hasiana, 2014). Ibu yang bersalin normal (pervagina) lebih cepat melakukan mobilisasi dini post partum sehingga dapat memungkinkan ibu untuk merawat bayinya sendiri khususnya dalam menyusui (Warsini, 2015).

Berdasarkan latar belakang tersebut, maka dianggap perlu untuk mengetahui faktor-faktor yang mempengaruhi pemberian ASI eksklusif pada bayi neonatal di Rumah Sakit Ibu dan Anak (RSIA) Pertiwi Makassar.

\section{METODE}

Penelitian ini merupakan penelitian Obsevasional dengan menggunakan rancangan cross sectional study untuk mengetahui faktor-faktor yang mempengaruhi pemeberian Air Susu Ibu (ASI) pada bayi neonatal di RSIA Pertiwi Makassar. Penelitian ini dilaksanakan pada bulan Februari sampai Mei 2017.

Responden pada penelitian ini adalah ibu yang melahirkan di RSIA Pertiwi sebanyak 155 orang. Data diperoleh melalui wawancara dengan menggunakan kuesioner.

Pengumpulan data dilakukan dengan dua cara yaitu data primer dan data 
sekunder. Data Primer seperti karakteristik responden, praktik pemberian ASI eksklusif, tingkat pengetahuan ibu tentang ASI eksklusif, dan pelaksanaan Inisiasi Menyusu Dini (IMD) diperoleh dengan metode wawancara menggunakan kuesioner. Data sekunder seperti gambaran lokasi penelitian dicatat dari dokumen pada instansi terkait di wilayah penelitian.

Data diolah dengan menggunakan program SPSS For Windows. Analisis data menggunakan Uji Chi Square untuk mengetahui hubungan antara tingkat pengetahuan ibu tentang ASI eksklusif, proses persalinan dan Inisiasi Menyusu Dini (IMD) dengan pemberian ASI eksklusif pada bayi neonatal di RSIA Pertiwi Makassar. Data disajikan dalam bentuk tabel, grafik dan narasi dengan berpedoman pada teori-teori dan hasil penelitian yang sesuai.

\section{HASIL}

\section{Proses Persalinan Responden}

Tabel 1

Distribusi Frekuensi Proses Persalinan

Responden di RSIA Pertiwi Makassar

\begin{tabular}{lcc}
\hline Proses Persalinan & $\mathrm{n}$ & $\%$ \\
\hline Normal & 92 & 59,4 \\
Sectio Caesarea $($ SC) & 63 & 40,6 \\
\hline Total & 155 & 100 \\
\hline
\end{tabular}

Berdasarkan tabel 1 dapat diketahui bahwa responden dengan proses persalinan normal sebanyak 92 orang $(59,4 \%)$, sedangkan proses persalinan Sectio Caesarea (SC) sebanyak 63 orang $(40,6 \%)$.

\section{Pelaksanaan Inisiasi Menyusu Dini (IMD)}

Tabel 2

Distribusi Frekuensi Pelaksanaan IMD di RSIA Pertiwi Makassar

\begin{tabular}{lrc}
\hline $\begin{array}{c}\text { Pelaksanaan } \\
\text { IMD }\end{array}$ & $\mathrm{n}$ & $\%$ \\
\hline IMD & 32 & 20,6 \\
Tidak IMD & 123 & 79,4 \\
\hline Total & 155 & 100 \\
\hline
\end{tabular}

Berdasarkan tabel 2 dapat diketahui bahwa responden yang melaksanakan IMD sebanyak 32 orang $(20,6 \%)$, sedangkan yang tidak melaksanakan IMD sebanyak 123 orang $(79,4 \%)$. Responden yang melaksanakan kontak dini sampai menyusui awal berakhir sebanyak 18 orang $(56,3 \%)$ dari 32 orang yang melaksanakan IMD.

\section{Pengetahuan Responden}

Tabel 3

Distribusi Frekuensi Pengetahuan Responden di RSIA Pertiwi Makassar

\begin{tabular}{lcc}
\hline Pengetahuan & $\mathrm{n}$ & $\%$ \\
\hline Baik & 18 & 11.6 \\
Kurang & 137 & 88,4 \\
\hline Total & 155 & 100 \\
\hline
\end{tabular}

Berdasarkan tabel 3 dapat diketahui bahwa responden dengan pengetahuan baik sebanyak 18 orang $(11,6 \%)$, sedangkan pengetahuan kurang sebanyak 137 orang $(88,4 \%)$. 
Pemberian ASI Eksklusif

Tabel 4

Distribusi Frekuensi Pemberian ASI

Eksklusif di RSIA Pertiwi Makassar

\begin{tabular}{ccc}
\hline ASI Eksklusif & $\mathrm{n}$ & $\%$ \\
\hline Eksklusif & 84 & 54,2 \\
$\begin{array}{c}\text { Tidak } \\
\text { Eksklusif }\end{array}$ & 71 & 45,8 \\
\hline Total & 155 & 100 \\
\hline
\end{tabular}

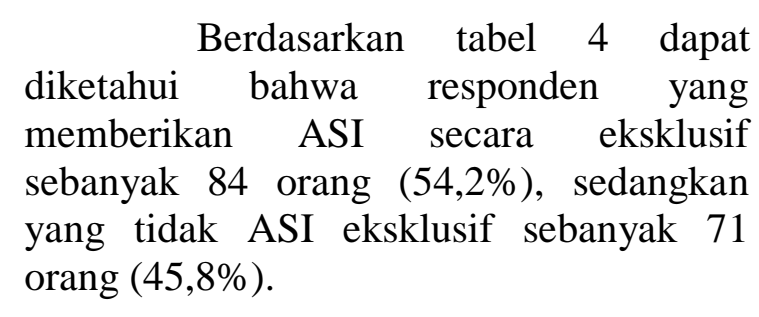

\section{Hubungan Proses Persalinan dengan Pemberian ASI Eksklusif pada Bayi Neonatal}

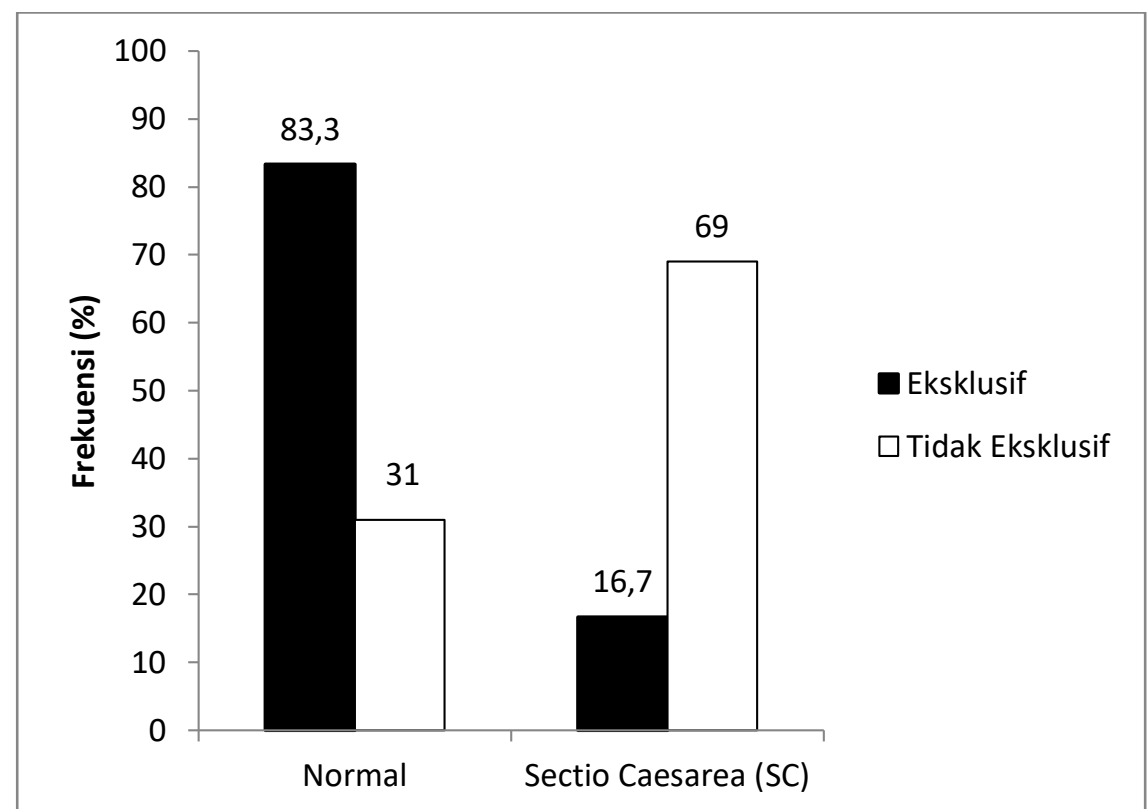

Grafik 1. Hubungan Proses Persalinan dengan Pemberian Air Susu Ibu (ASI) pada Bayi Neonatal di RSIA Pertiwi Makassar

Berdasarkan grafik 1 dapat dilihat bahwa responden dengan persalinan normal sebagian besar memberikan ASI eksklusif yaitu sebesar $83,3 \%$ dan yang tidak ASI eksklusif sebesar $31 \%$. Sedangkan responden dengan proses persalinan Sectio Caesarea (SC) sebagian besar tidak ASI eksklusif yaitu sebesar $69 \%$ dan yang memberikan ASI eksklusif sebesar $16,7 \%$.
Berdasarkan hasil uji statistik Chi Square diperoleh nilai $p 0,0001 \quad(<0,05)$ yang artinya ada hubungan bermakna antara proses persalinan dengan pemberian Air Susu Ibu (ASI) pada bayi neonatal di RSIA Pertiwi Makassar. Hal ini disebabkan karena responden dengan proses persalinan Sectio Caesarea (SC) tidak melaksanakan IMD dimana IMD merupakan kunci keberhasilan menyusui. 


\section{Hubungan Pelaksanaan Inisiasi Menyusu Dini (IMD) dengan Pemberian ASI Eksklusif pada Bayi Neonatal}

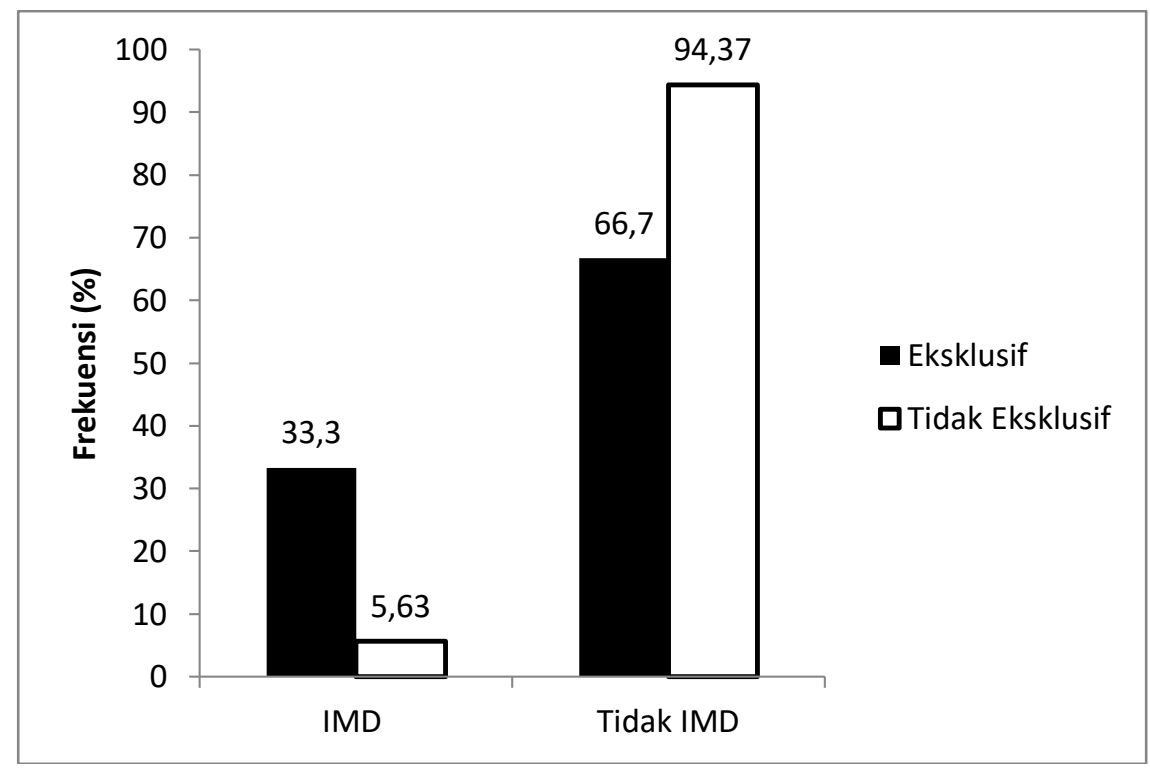

Grafik 2. Hubungan Pelaksanaan IMD dengan Pemberian Air Susu Ibu (ASI) pada Bayi Neonatal di RSIA Pertiwi Makassar

Berdasarkan grafik 2 dapat dilihat bahwa sebagian besar responden yang melaksanakan IMD memberikan ASI eksklusif yaitu sebesar $33,3 \%$ dan yang tidak ASI eksklusif sebesar 5,63\%. Sedangkan responden yang tidak melaksanakan IMD sebagian besar tidak ASI eksklusif yaitu sebesar $94,37 \%$ dan yang memberikan ASI eksklusif sebesar $66,7 \%$.

Berdasarkan hasil uji statistik Chi Square diperoleh nilai $p 0,0001 \quad(<0,05)$ yang artinya ada hubungan bermakna antara pelaksanaan IMD dengan pemberian Air Susu Ibu (ASI) pada bayi neonatal di RSIA Pertiwi Makassar.

\section{Hubungan Pengetahuan Ibu dengan Pemberian ASI Eksklusif pada Bayi Neonatal}

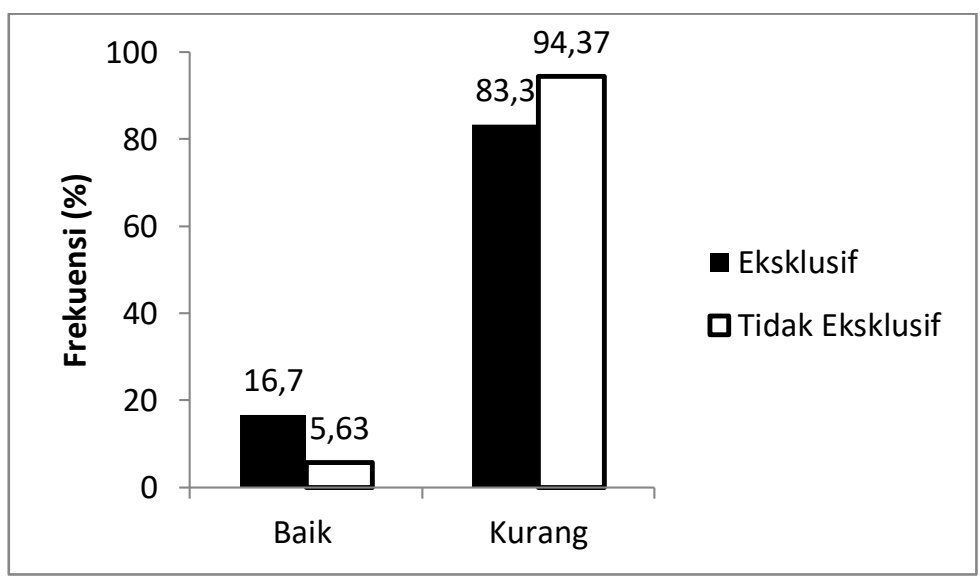

Grafik 3. Hubungan Pengetahuan dengan Pemberian Air Susu Ibu (ASI) pada Bayi Neonatal di RSIA Pertiwi Makassar 
Berdasarkan grafik 3 dapat dilihat bahwa sebagian besar responden yang memiliki pengetahuan baik memberikan ASI eksklusif yaitu sebanyak $16,7 \%$ dan yang tidak ASI eksklusif sebesar 5,63\%. Sedangkan yang memiliki pengetahuan kurang sebagian besar tidak memberikan ASI eksklusif yaitu sebesar $94,37 \%$ dan yang memberikan ASI eksklusif sebesar $83,3 \%$.

Berdasarkan hasil uji statistik $C h i$ Square diperoleh nilai $p \quad 0,043 \quad(<0,05)$ yang artinya ada hubungan bermakna antara pengetahuan ibu dengan pemberian Air Susu Ibu (ASI) pada bayi neonatal di RSIA Pertiwi Makassar.

\section{PEMBAHASAN}

Berdasarkan Peraturan Pemerintah Nomor 33 Tahun 2012 Air Susu Ibu (ASI) eksklusif adalah ASI yang diberikan kepada bayi sejak dilahirkan selama enam bulan, tanpa menambahkan dan/atau mengganti dengan makanan atau minuman lain (kecuali obat, vitamin, dan mineral).

Berdasarkan hasil penelitian pada 155 responden di RSIA Pertiwi Makassar, diperoleh hasil bahwa responden yang memberikan ASI secara eksklusif sebanyak $54,2 \%$ dan yang tidak memberikan ASI eksklusif sebanyak 45,8\%. Walaupun cakupan pemberian ASI eksklusif di RSIA Pertiwi hampir setara dengan cakupan nasional $(55,7 \%)$ tetapi kondisi ini juga dapat mencerminkan bahwa perilaku ibu terhadap pemberian ASI eksklusif kepada bayinya relatif rendah dibandingkan target pemerintah yaitu $80 \%$ bayi $0-6$ bulan harus diberikan ASI secara eksklusif. Hasil wawancara dengan responden ditemukan beberapa faktor mengapa responden tidak memberikan ASI secara eksklusif, antara lain; terjadi pemisahan antara ibu dan bayi sesaat setelah melahirkan, ASI belum keluar dan produksi ASI masih sedikit.

Berdasarkan hasil penelitian menunjukkan bahwa sebagian besar responden $(59,4 \%)$ dengan proses persalinan normal dan $40,6 \%$ responden dengan proses persalinan Sectio Caesarea (SC). Berdasarkan hasil penelitian menunjukkan bahwa ada hubungan antara proses persalinan dengan pemberian ASI di RSIA Pertiwi Makassar dengan $p$ value 0,0001. Hal ini disebabkan karena responden dengan proses persalinan Sectio Caesarea (SC) tidak melaksanakan IMD sedangkan IMD merupakan kunci keberhasilan menyusui.

Penelitian ini sejalan dengan penelitian terdahulu yang dilakukan Warsini (2015) yang menyatakan bahwa terdapat hubungan antara jenis persalinan dengan keberhasilan ASI eksklusif. Pada ibu yang melahirkan secara pervagina akan lebih cepat melakukan mobilisasi dini post partum karena ibu sudah diperbolehkan bangun dari tempat tidur sebelum 48 jam dan dianjurkan agar secepat mungkin berjalan. Mobilisasi yang dini setelah melahirkan akan memungkinkan ibu dapat segera merawat sendiri bayinya termasuk dalam hal menyusui. Bayi dapat sedini mungkin mendapatkan ASI dari ibunya dan menghindarkan bayi dari pemberian asupan makanan prelakteal yang akan menggagalkan pemberian ASI eksklusif.

Penelitian lain yang dilakukan Hasiana, dkk (2014) menyatakan bahwa terdapat hubungan antara persalinan caesar dengan keberhasilan pemberian ASI eksklusif. Ketidaknyamanan dan nyeri merupakan kondisi psikis setelah persalinan. Produksi ASI sangat dipengaruhi oleh kondisi psikis tersebut sehingga ibu akhirnya tidak berhasil menyusui dengan baik.

Berdasarkan hasil uji univariat menunjukkan bahwa mayoritas ibu yang melahirkan di RSIA Pertiwi Makassar tidak melaksanakan IMD $(79,4 \%)$ dibandingkan dengan ibu yang melaksanakan IMD (20,6\%). Cakupan pelaksanaan IMD di RSIA Pertiwi masih rendah jika dibandingkan dengan cakupan 
nasional sebesar 49,7\%. Dari hasil wawancara dengan responden diperoleh keterangan bahwa mereka tidak melaksanakan IMD karena beberapa faktor antara lain; proses persalinan caesar, komplikasi saat persalinan, proses penjahitan setelah persalinan, bayi membutuhkan penanganan khusus, serta adapula bayi yang diletakkan di dada ibu sesaat setelah melahirkan namun dengan waktu kurang dari 1 jam. Rendahnya pelaksanaan IMD pada persalinan caesar terjadi karena barbagai faktor seperti pemisahan ibu dan bayi serta ketidaknyamanan dan nyeri setelah operasi sehingga membutuhkan waktu lebih lama untuk memulihkan diri sebelum mampu untuk menyusui bayinya.

Berdasarkan hasil uji bivariat menunjukkan bahwa ada hubungan bermakna antara pelaksanaan IMD dengan pemberian ASI di RSIA Pertiwi Makassar dengan $p$ value 0,0001 .

Hal ini sejalan dengan teori yang menyatakan bahwa IMD merupakan kunci yang sangat penting dalam proses menyusui. Bayi yang melakukan IMD akan lebih berhasil menyusu karena bayibayi tersebut sudah berusaha sendiri tanpa bantuan siapapun di awal kelahirannya. Kemampuan bayi menyusu sendiri ini juga akan membuat proses menyusu menjadi efektif karena bayi bisa melekat dengan baik (Umar, 2014).

Hasil penelitian ini sejalan dengan hasil penelitian Parwito (2016) yang menunjukkan bahwa terdapat hubungan yang kuat antara pelaksanaan IMD dengan pemberian ASI eksklusif. Ibu yang melakukan IMD berpeluang 16 kali lebih banyak untuk memberikan ASI eksklusif daripada ibu yang tdak melakukan IMD.

Pengetahuan ibu tentang ASI eksklusif adalah pengetahuan ibu tentang ASI dalam jumlah cukup merupakan makanan terbaik dan dapat memenuhi kebutuhan gizi bayi selama enam bulan pertama. Berdasarkan hasil uji univariat diperoleh bahwa mayoritas ibu yang melahirkan di RSIA Pertiwi Makassar memiliki tingkat pengetahuan tentang ASI eksklusif kurang $(88,4 \%)$ dibanding ibu dengan tingkat pengetahuan baik $(11,6 \%)$. Dari kondisi ini dapat dilihat bahwa responden di RSIA Pertiwi Makassar belum memahami pengertian dan maksud dari program ASI eksklusif.

Berdasarkan hasil uji bivariat menunjukkan bahwa ada hubungan bermakna antara tingkat pengetahuan ibu dengan pemberian ASI di RSIA Pertiwi Makassar dengan $p$ value 0,043 .

Hasil ini sejalan dengan teori yang menyatakan bahwa pengetahuan atau kognitif merupakan domain yang sangat penting dalam membentuk tindakan seseorang. Dari pengalaman dan penelitian terbukti bahwa perilaku yang didasari pengetahuan lebih langgeng daripada perilaku yang tidak disadari pengetahuan (Notoadmodjo, 2003).

Hasil penelitian ini juga sejalan dengan penelitian yang dilakukan Rachmaniah (2014) yang menyebutkan bahwa terdapat hubungan yang bermakna antara pengetahuan ibu tentang ASI dengan tindakan ASI eksklusif, dimana semakin tinggi tingkat pengetahuan ibu tentang ASI maka akan mempengaruhi pola pikir dan sikap ibu sehingga akan menimbulkan perilaku positif untuk memberikan ASI eksklusif.

\section{KESIMPULAN}

1. Responden dengan proses persalinan normal cenderung memberikan ASI eksklusif pada bayi neonatal di RSIA Pertiwi Makassar.

2. Responden yang melaksanakan IMD cenderung memberikan ASI eksklusif pada bayi neonatal di RSIA Pertiwi Makassar.

3. Responden yang memiliki pengetahuan baik cenderung memberikan ASI eksklusif pada bayi neonatal di RSIA Pertiwi Makassar. 


\section{SARAN}

1. Perlu peningkatan pengetahuan tentang pentingnya pemberian ASI eksklusif dan IMD pada bayi melalui edukasi saat pemeriksaan kehamilan.

2. Diharapkan untuk meneliti lebih lanjut tentang Inisiasi Menyusu Dini (IMD) dimana kriteria dari IMD tidak hanya bayi diletakkan di dada ibu selama minimal satu jam tetapi bayi juga telah mendapatkan kolostrum selama pelaksanaan IMD. Diharapkan juga untuk meneliti tentang ASI eksklusif dengan mengambil variabel-variabel lain mengingat masih rendahnya cakupan ASI eksklusif khususnya di Rumah Sakit Ibu dan Anak (RSIA) Pertiwi Makassar.

\section{DAFTAR PUSTAKA}

Amir, Aswita. 2016. Pengaruh Konseling Menyusui Terhadap Perilaku Menyusui, Kondisi Payudara Dan Pertumbuhan Bayi Di Kota Makassar. Makassar: Poltekkes Kemenkes Makassar.

Djami, dkk. 2013. Frekuensi Pemeriksaan Kehamilan, Konseling Laktasi, dan Pemberian Air Susu Ibu Eksklusif. Bandung: Fak. Kedokteran Univ. Padjadjaran.

Hasiana, dkk. 2014. Pengaruh Sectio Caesarea Tehadap Keberhasilan Eksklusif. Bandung: Fakultas Kedokteran Universitas Sebelas Maret.

Kementerian Kesehatan RI. 2016. Profil Kesehatan Indonesia 2015. Jakarta: Kementerian Kesehatan RI.

Notoadmodmojo, Soekidjo.2003.Metodologi Penelitian Kesehatan. Jakarta: Rineka Cipta.

Parwito, Irena F. 2015. Hubungan Inisiasi Menyusu Dini dengan Pemberian Air Susu Ibu Eksklusif di Posyandu Puskesmas Gajahan Surakarta.
Surakarta: Universitas Katolik Widya Mandala.

Rachmaniah, Nova. 2014. Hubungan Tingkat Pengetahuan Ibu Tentang Asi dengan Tindakan ASI Eksklusif. Surakarta: Fak. Kedokteran univ. muhammadiyah.

Umar, Nia. 2014. Multitasking Breastfeeding Mama. Jakarta: Puspa Swara

Warsini. 2015. Hubungan Antara Jenis Persalinan, Tingkat Pendidikan, Tingkat Pendapatan Dan Status Bekerja Ibu Dengan Keberhasilan ASI Eksklusif 6 (Enam) Bulan Di Kecamatan Baki Kabupaten Sukoharjo. Surakarta: Universitas Sebelas Maret. 